\title{
TOXICO-ECOLOGICAL ANALYSIS OF MERCURY-CONTAINED WASTE MANAGEMENT IN UKRAINE
}

\author{
O. Pykhtieieva, D. Bolshoy, L. Shafran \\ SE Ukrainian Research Institute of Transport Medicine, Odessa, Ukraine
}

\begin{abstract}
Relevance. The multifaceted intersectoral problem of human security in contact with mercury has gained global significance in the twentieth century, it is relevant today. Considerable attention is paid to the environmental and hygienic aspects of mercury hazards in the field related to the production and disposal of waste containing $\mathrm{Hg}$.

The Aim of the Research. Analyze the data of own research on mercury content in the environment in connection with the management of mercury-containing waste and justify a set of preventive environmental and hygienic, technological and organizational measures to improve safety, public health and improve the environment in the region and the country in general.

Materials and Methods. Sampling, sample preparation and determination of mercury content in environmental facilities and bioassays were performed according to MI "Methodical instructions for the determination of mercury in biological material, air, drinking water, food products and the environment." The concentration of mercury was measured by the method of AAS "cold steam" on the upgraded device "Yulia-2M". The mercury content in soil and air at the spontaneous dump of mercury lamps in Odessa region, on the border of the sanitary protection zone and in the air of the working zone of the enterprise for utilization of mercury lamps was studied. For sample preparation, chemically pure nitric acid (56\%) was used, to reduce mercury during the analysis of chemically pure tin (II) chloride. Results and Conclusions. Mercury lamps have been shown to be hazardous to the environment and human health without proper disposal. Mercury lamps should be collected and disposed of as hazardous waste not only in industrial facilities but also in the general public. The formation of spontaneous unauthorized landfills of mercury lamps is unacceptable. The problem of environmental monitoring needs to be addressed at the state level with the mandatory involvement of specialists in the field of hygiene, toxicology and analytical chemistry of heavy metals in cases of violations to assess the level of danger and make informed decisions on approaches to elimination of mercury sources.
\end{abstract}

Key Words: mercury, mercury lamps, ecology.

Introduction. Although the use of mercury $(\mathrm{Hg})$ by mankind has been going on for centuries, fundamental and applied geochemical, ecological, hygienic and toxicological studies aimed at comprehensively studying and solving the problem of human safety of one of the most toxic chemical elements have been active since the mid-20th century, including in Ukraine [1-5].On the one hand, this was due to the growth of production and use of $\mathrm{Hg}$ in various spheres of economy and life, on the other hand, the growing number of acute, chronic poisonings, mercury-dependent pathological changes in the human body $[6,7]$. Among these is the infamous Minamata disease, which arose after a long diet of one of the regions of Japan contaminated with $\mathrm{Hg}$ seafood $[8,9]$. The multifaceted intersectoral problem of human security in contact with mercury has gained global significance, primarily due to its anthropogenic component. The prevalence of natural mercury on different continents of the planet has become quite dangerous for the environment. Anthropogenic sources are characterized by a more local and concentrated nature of emissions (for example, in China and India, the increase in emissions is due to $\mathrm{Hg}$ emissions from coal-fired power plants and small-scale gold mining) [10-12]. Purposeful management actions contribute the most to the reduction of this negative phenomenon. The effectiveness of the latter depends to a large extent on the development of research and the updating of our knowledge and capabilities for integrated research related to $\mathrm{Hg}$, risks to the environment and human health.

Among the fundamentally important achievements of modern biogeochemistry of $\mathrm{Hg}$, which have global scientific and theoretical significance, should be highlighted according to Blum JD et al., 2014; D. Obrist et al. $2018[13,14]$ such as:

1. Establishing the presence and functioning of the planetary mercury cycle.

2. Development and application of the method of stable isotopes for tracking sources, biogeochemical cycle and reactions involving $\mathrm{Hg}$ in the environment.

3. Substantiation of more informative and 
adequate global and regional models that reproduce the processes of accumulation, distribution and transformation of $\mathrm{Hg}$ in the environment.

4. A new concept of the contribution of flora to the absorption and deposition of $\mathrm{Hg}$ is proposed, which is estimated at 1020$1230 \mathrm{Mg} /$ year.

5. Significant progress has been made in the fundamental problem of methylation and demethylation of mercury by microorganisms, which is a prerequisite for the formation and circulation of toxic forms of $\mathrm{Hg}$ in the environment, transport and bioavailability to biota and humans, as well as its neurotoxic properties.

Successful development and numerous examples of implementation of global problems of bioecological hygiene and geochemistry of $\mathrm{Hg}$ do not diminish the importance of regional and local issues of mercury safety and further search for effective demercurization systems. Due to the complex of unique physical and chemical properties, $\mathrm{Hg}$ is a component of many production processes, so it is used in a large number of appliances and devices. In some cases, its use greatly facilitates or makes it cheaper to achieve appropriate technical and technological results [15]. Therefore, it is no coincidence that there are about 150 types of production, in the technologies of which $\mathrm{Hg}$ is used or emitted. More than 80 occupations are associated with longterm contact with $\mathrm{Hg}$, which is confirmed by field research in the workplace and the results of job certification conducted by us. The latest technologies for the production of chlorine and caustic alkalis that do not use mercury are four to six times more expensive than mercurycathode [1]. Mercury-containing power supplies are not only cheaper, but also have better voltammetric characteristics, greater capacity, durability than their mercury-free counterparts. Therefore, despite measures to limit the use of $\mathrm{Hg}$, the list of hazardous industries due to this chemical factor is quite large and diversified, and the requirements for the complete exclusion of mercury from human life by technologists and operators are considered premature [16].

And yet, a significant achievement of the efforts of scientists, practitioners, international organizations, the public was a significant reduction in $\mathrm{Hg}$ concentrations in the produc- tion environment. Not only the sources of $\mathrm{Hg}$ in the body, but also the current levels have fundamentally changed $[17,2]$. Today, most of them are low-intensity factors. Accordingly, the priorities of research, practice and efforts of toxicologists and hygienists in the field of mercury safety have changed, within which works on the problems of micro- and ultramicromercurialism dominate, that is, dangerous effects on the body of small doses and concentrations of $\mathrm{Hg}$, the study of the biological effects of which still remains a topical problem of modern toxicology and a topic of scientific and public debate. At the same time, much more attention is being paid to the environmental and hygienic aspects of mercury hazards in the field, related not only to the production of mercury-containing products and relevant technological schemes, but also to the management of hazardous $\mathrm{Hg}$ waste.

Thorough research is being conducted in various countries of the world, environmentally friendly technologies are being developed, regional, national and international programs are being developed and successfully implemented. Thus, the anthropogenic risk of mercury loading of territories, reservoirs and food pollution is significantly reduced. The problem of demercurization of all spheres of human life (in terms of limiting the levels of contamination to Clarke number and the maximum allowable) has become potentially possible and real, although there are significant difficulties and obstacles along the way. Since the authors of this work have been actively solving certain scientific and practical aspects of this complex problem (mainly at the regional level) for many years, we considered it necessary to dwell on them in more detail and outline ways to solve them successfully. It should be emphasized that the prevention of the negative impact of $\mathrm{Hg}$ on human health and the biosphere requires not only permanent environmental and hygienic monitoring, but constant, well-planned comprehensive work and joint efforts of ecologists, hygienists, toxicologists, technologists and production organizers with the support of the authorities and the public.

The Purpose of the Study. Analyze the data of own research on mercury content in the environment in connection with the management of mercury-containing waste and justify a set of preventive environmental and hygienic, technological and organizational measures 
to improve safety, public health and improve the environment in the region and the country in general.

Materials and Methods. Sampling, sample preparation and determination of mercury content in environmental facilities and bioassays were carried out in accordance with the MI "Methodical instructions for the determination of mercury in biological material, air, drinking water, food products and the environment." [18]. The concentration of mercury was measured by the method of AAS "cold steam" on the upgraded device "Yulia-2M". The mercury content in soil and air at the spontaneous dump of mercury lamps in Odessa region, on the border of the sanitary protection zone and in the air of the working zone of the enterprise for utilization of mercury lamps was studied. For sample preparation chemically pure nitric acid (56\%) was used, to reduce mercury during the analysis of chemically pure tin (II) chloride.

Results and Discussion. Over the past 20 years, our laboratory has been systematically measuring mercury content in the air of Odessa, in the air of the working area of the mercury lamp disposal company, near the ship waste incinerator, soils of sanitary protection zones of household waste dumps, in residential buildings, educational and medical institutions after emergencies related to the spill of metallic mercury $(\mathrm{Hg})$. In addition, we conduct research on the content of $\mathrm{Hg}$ in the blood, urine and hair of the population under the direction of doctors suspected of mercury intoxication. The obtained data indicate that low-dose sources of $\mathrm{Hg}$ exposure predominate in communal conditions. For the population, these are most often broken mercury thermometers and used fluorescent lamps.

All types of fluorescent lamps contain $\mathrm{Hg}$ (from 2.3 to $70 \mathrm{mg}$ per lamp). For all the economic advantages of mercury fluorescent lamps over incandescent lamps, their main disadvantage is that after the end of their service life, they turn into hazardous waste contaminated with $\mathrm{Hg}$, a toxic substance of hazard class I. Therefore, according to the Resolution of the Cabinet of Ministers of 13.07.2000 № 1120 "On approval of the Regulations on control over transportation of hazardous waste and their utilization", Yellow and Green lists of waste, all products of this category are classified as hazardous waste, subject to mandatory removal at the end of life service and special disposal methods. As can be seen from the data in Table 1, the mercury content, depending on the model is from 0.01 to $0.03 \%$ of the total mass of waste.

Table 1 also shows that used lamps also contain other precious metals and renewable secondary materials that can be used in the same way as for the disposal of batteries [20,21].

This issue is addressed differently in different countries. In Germany, for example, there are 3,100 collection points for mercury-containing lamps $(1,715$ in the utilities sector and 1,390 in retail outlets), as well as 400 large points that serve facilities with a large volume of such products (industrial and public buildings). The address of the nearest collection point can be found on a special website. Lamps are accepted in unlimited quantities and free of charge. However, according to citizens, the number of reception points is insufficient and they are located outside the reach. According to the German Institute of Urbanism, less than $40 \%$ of all gas-discharge lamps are properly disposed of in this country. In Bulgaria, importers and manufacturers are responsible for collecting and disposing of mercury lamps. Disposal is free for the population. In Belgium, a specialized company, Recupel, became the manufacturer and distributor of lamps in 2001. The consumer pays a fee when buying a lamp and at the end of its service life hands it over to the municipal storage point at the municipality. In Romania, the lamps are collected and disposed of by the Recolamp Association, founded by the lamp manufacturers Philips, Osram, Narva and General Electric. The disposal fee is charged to the consumer when purchasing the lamp. In France, used fluorescent lamps are collected by waste collectors $(55 \%)$, lamp distributors $(23 \%)$, assembly organizations $(15 \%)$, and municipalities $(7 \%$ of all lamps). The activities of collection points are controlled directly by the state. In the Czech Republic, used lighting equipment is collected by the specialized public organization Ekolamp, established in 2002. There are about 1,300 collection points throughout the country. You can also take them to the store when buying a new product. In the United States, the collection and disposal of lamps is subject to an environmental tax (several cents per lamp). Collection point networks are organized differently in each state - collection in 
Waste composition of used mercury lamps [19]

\begin{tabular}{|l|c|c|c|c|c|c|}
\hline \multirow{2}{*}{ Material } & \multicolumn{7}{|c|}{ Lamp type, material content,\% } \\
\cline { 2 - 7 } & $\begin{array}{c}\text { MBFU } \\
\mathbf{1 2 5}\end{array}$ & $\begin{array}{c}\text { MBFU } \\
\mathbf{2 5 0}\end{array}$ & $\begin{array}{c}\text { MBFU } \\
\mathbf{7 0 0}\end{array}$ & $\begin{array}{c}\text { MBFU } \\
\mathbf{1 0 0 0}\end{array}$ & FL 20-2 & $\begin{array}{c}\text { Tubular } \\
\text { lamps* }\end{array}$ \\
\hline Glass flasks & 74,20 & 72,56 & 71,43 & 71,42 & 91,40 & 87 \\
\hline Glass burner & 6,54 & 8,26 & 12,66 & 14,08 & - & - \\
\hline Porcelain & 5,10 & 0,45 & 4,91 & 3,93 & - & - \\
\hline Mica & - & 0,77 & 0,50 & 0,50 & - & - \\
\hline Mastic & 2,42 & 1,82 & 1,01 & 1,04 & 3,0 & - \\
\hline Iron & 0,24 & 0,3 & 0,25 & 0,19 & 0,07 & - \\
\hline Nickel & 5,25 & 4,14 & 3,35 & 2,84 & - & - \\
\hline Copper & 0,17 & 0,8 & 0,41 & 0,19 & 0,30 & - \\
\hline Brass & 4,125 & 8,08 & 4,58 & 3,95 & 0,68 & - \\
\hline Lead & 0,94 & 0,65 & 0,25 & 0,22 & 0,29 & 2,55 \\
\hline Aluminum & - & - & - & - & 2,90 & 5 \\
\hline Mercury & 0,01 & 0,01 & 0,03 & 0,03 & 0,06 & 0,150 \\
\hline Tungsten & 0,59 & 2,165 & 0,34 & 1,40 & 0,02 & - \\
\hline Getinax & - & - & - & - & 0,31 & - \\
\hline
\end{tabular}

*Note: According to GOST6825-74, GOST-1639-93

stores or collection programs sponsored by the state or utilities. The program "Easy Pack" sale of the boxes adapted for storage of lamps of various types turned out to be very successful. The cost of transportation and disposal is included in the price of the box.

In Russia, according to current legislation, waste is the property of the person who produces it, so people and organizations are obliged to pay for the disposal of fluorescent lamps. In almost all regions, there are extremely few waste collection points (for the entire Ural Federal District - 11), only in Moscow and the region there are enough of them (approximately 1,200 points). Such a developed network is the result of a targeted order from the Moscow government in 2010.

Thus, waste disposal systems in different countries in the European Union, the United States and the world differ significantly and depend on the attitude of society, location and financial capabilities. The problem of mercury lamp disposal in Ukraine also has a history. Already in the last decade of the last century, attempts were made to demercurize lamps at installations of various manufacturers in Donetsk, Kirovohrad and other regions. Unfortunately, after some success, it has become clear that there are many unresolved issues, including the organization of the collection, temporary storage and transportation of this hazardous waste to recycling plants, as well as the reimbursement of related costs. This was clearly demonstrated by the example of the organization of a collection point for fluorescent lamps at the Odessa Biotechnological Institute of the Academy of Agrarian Sciences of Ukraine [22].In a short time of experimental work, more than 50,000 lamps, $200 \mathrm{~kg}$ of metallic mercury and several tons of other mercury-containing industrial and household waste were collected there. In the future, it was planned to organize municipal collection points, but the idea was not implemented. For many years, there has been a debate about the cost of disposal, which should be included in the cost of goods and received by the state in the form of environmental tax from companies that produce or import dangerous products. Unfortunately, 
Ukraine does not have sufficient infrastructure, there are no state hazardous waste collection points. The country does not have a fullfledged system for receiving mercury-containing waste, nor is there an effective information for individuals about the rules and places of their utilization. If companies have the opportunity to enter into contracts for the disposal of mercury waste, then there is only one way for the population to dispose of it - to dispose of it in household waste. The work of environmental activists to set up free collection and disposal of hazardous waste for the population does not find support from local authorities, even in large cities. What to say about small settlements? How many citizens in Ukraine know that lamps, thermometers, manometers need to be recycled, and where to take them to? Local governments have obviously ignored important information availability to citizens.

An important, and perhaps the most important, link in the process of disposing of lamps is the consumers themselves. The success of all measures to create a system for the disposal of mercury lamps depends on their knowledge and activity. Our compatriots need to know how to handle modern mercury lamps, where to carry them after the end of their service life and what to do in case of mechanical damage to the bulb. It is necessary to inform the population through television, radio, Internet and street advertising. The packaging of the lamps should be accompanied by complete information on its use and disposal (a memo for the buyer) with information on where to hand over the lamps, as well as the rules of conduct in case the lamp breaks. Thus, establishing the utilization of used fluorescent lamps in Ukraine is a priority to prevent anthropogenic mercury pollution.

At the end of 2019, our laboratory participated on a volunteer basis in the liquidation of a spontaneous landfill of mercury lamps near Odessa. In the sanitary protection zone of the industrial district, unknown people threw
3 trucks of mercury lamps into the open air. It seemed that the lamps were collected and prepared for disposal: most of the lamps were wrapped in paper and folded in cardboard boxes. On the part of the paper in which the lamps were packed, there was a seal of the south-western railway. The integrity of some lamps was violated: phosphor powder with mercury got into the soil, and the wind carried it across the territory.

In fig. 1 - photos of a spontaneous dump of spent mercury lamps, which were criminally unloaded in the open air on the border of Odessa, near the village of Krasnosilka.

We conducted sanitary and chemical studies of environmental objects (air, soil) on the territory of the landfill. Cold vapor measurements showed that the mercury content near the landfill was 23 times higher than the TLV for ambient air $\left(0.3 \mu \mathrm{g} / \mathrm{m}^{3}\right)$, and the mercury content in the soil depended on the distance to the landfill (Table 2).

Exceeding the TLV is observed only in samples taken directly under the pile of lamps and next to them. Probably, the excess is due to the phosphor, which was poured on the ground from broken lamps. But with the destruction of lamps and the spread of phosphors by wind, the area of pollution may increase. Substantially mercury-contaminated soil will be a source of low-dose mercury for many years to come. In addition, air sampling was performed at a temperature of $+7^{\circ} \mathrm{C}$ in windless weather. It is known that with increasing temperature, the evaporation of mercury increases. In a landfill, whole lamps will sooner or later be destroyed and pollute the environment. Moreover, the presence of such landfills, unfortunately, is evidence not only of the low culture of our citizens, but also the negligence of many officials.

The letter was sent by us to the Department of Ecology and Natural Resources of the Odessa Regional State Administration with the location of the landfill and the results of meas-

Table 2

Mercury content in soil samples depending on the distance to the lamps

\begin{tabular}{|c|c|c|c|}
\hline № sample & Distance to lamps, $\mathbf{M}$ & Hg content, $\mathbf{m g}$ / $\mathbf{k g}$ & TVL for soils, $\mathbf{m g}$ / kg \\
\hline 1 & 0 & 56,8 & \multirow{2}{*}{2,1} \\
\hline 2 & 1 & 2,11 & \\
\hline 3 & 3 & 0,214 & \\
\hline 4 & 5 & 0,072 & \\
\hline
\end{tabular}



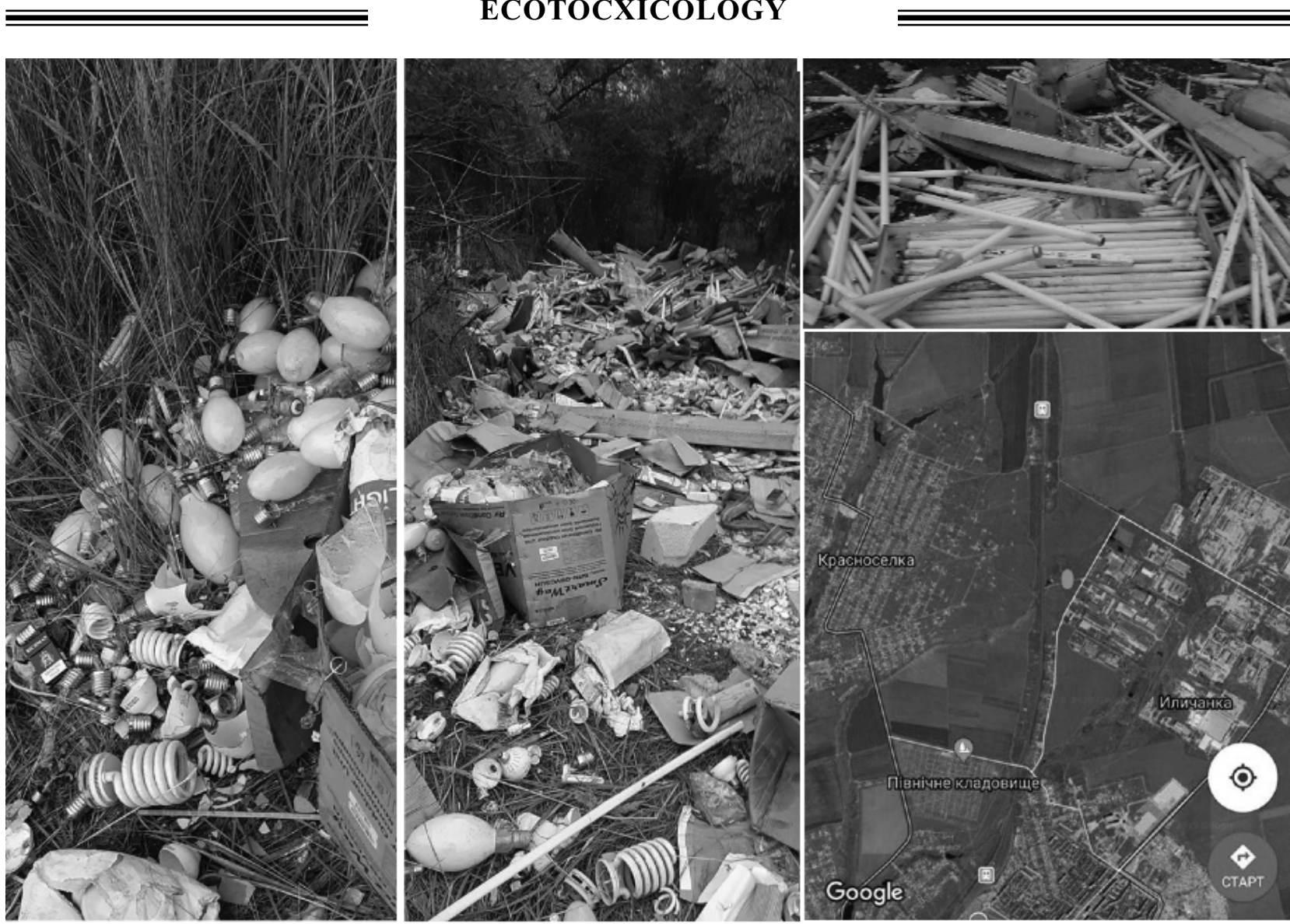

Fig. 1. Spontaneous dump of mercury-containing waste in the Odessa region.

urements, after which the landfill was liquidated by the Krasnosilsk village council. A photo report (Fig. 2), a copy of the contract for the disposal of lamps and a letter of reply were provided by us. From the photo report we saw that the cleaning was carried out without the use of PPE of the respiratory system, and the soil after cleaning remained contaminated with a phosphor and crushed glass. Unfortunately, the regional administration did not consider it necessary to carry out additional measurements of mercury content or to hold consultations on further actions, taking into account the typical nature of the recorded extreme situation.

Of course, such treatment of mercury-containing waste, when it enters landfills, is unacceptable and impossible in a civilized country. How many more such landfills are there across Ukraine? Unfortunately, such cases are not isolated.

In October 2013, an unauthorized landfill of fluorescent lamps was liquidated in the Chernihiv region, which was discovered near the village of Zmitniv, Sosnytsia district. In 2017, specialists of the State Ecological Inspectorate in Vinnytsia region discovered a landfill of used fluorescent lamps [23]. In
November 2019, environmental inspectors discovered an unauthorized landfill of used fluorescent lamps near the village of Lipnyky in the Pustomyty region [24]. Already in February 2020, environmental inspectors discovered an unauthorized landfill near the village of Zymna Voda in the Lviv region. Upon departure to the scene together with journalists and representatives of Zymnovodivska UTC it was established that between the country cooperative "Dary Pryrody" and the railway track there were illegally unloaded used fluorescent lamps in two areas of $4 \times 5 \mathrm{~m}$ (approximately one truck) and $4 \times 12 \mathrm{~m}$ (approximately) [25]. In April 2020, a pile of used fluorescent lamps was found in a former limestone quarry near the Gorodok district center [26]. This situation is unacceptable and does not meet European environmental safety standards and general rules for waste management.

In Odessa, there is an enterprise that provides disposal of used mercury lamps. RPC "Ukr Eko Prom" provides services for the organization of disposal of fluorescent lamps, works in the legal field. Since 2015, our laboratory has an agreement with the company on analytical measurements of mercury content 

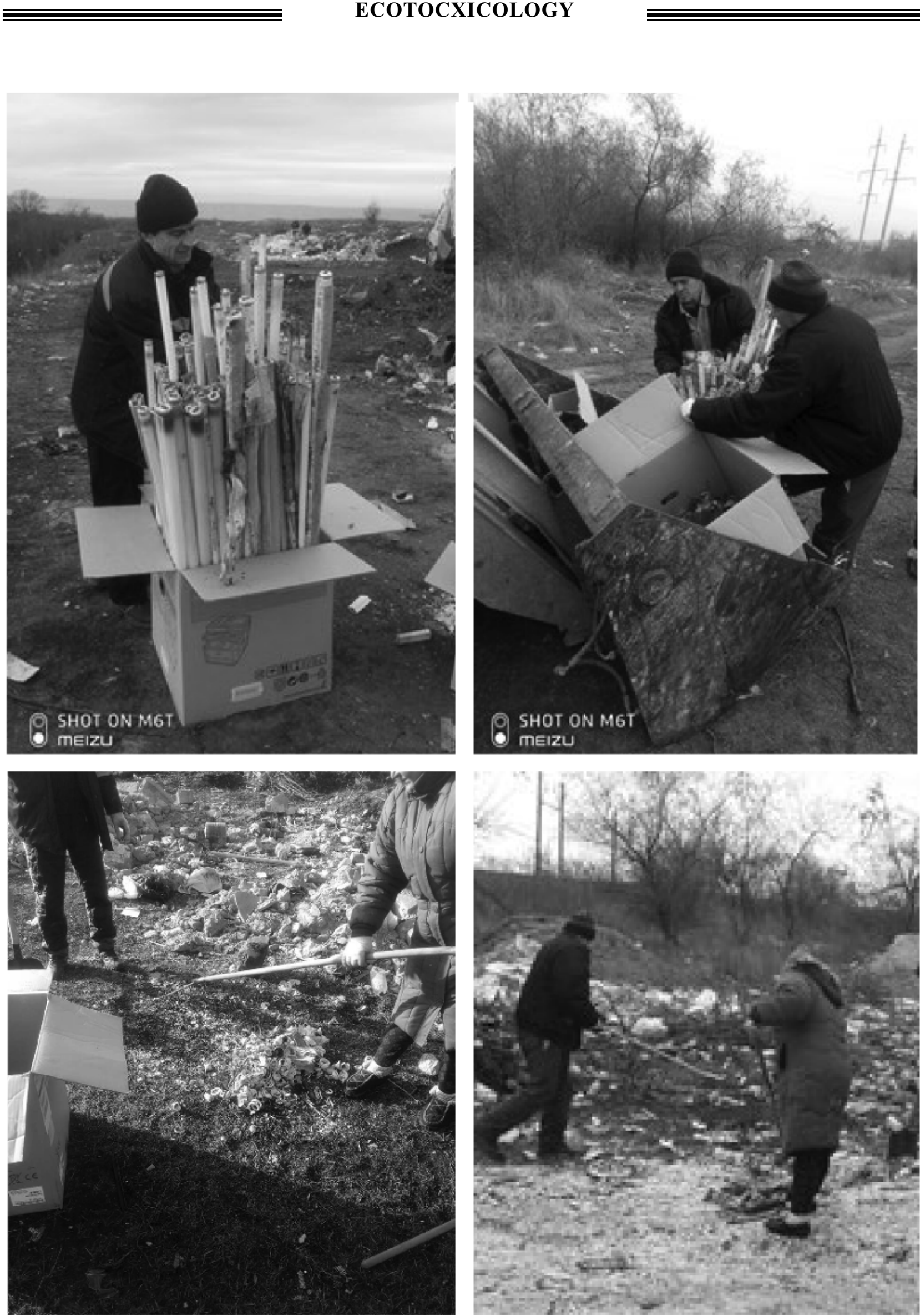

Fig. 2. Elimination of spontaneous landfill of mercury-containing waste in Odessa region. 
in the air of the working area, atmospheric air and in the soil at the border of the sanitary protection zone. We can reasonably state that the disposal is carried out in compliance with all safety measures for the operator and the environment. We can reasonably state that the disposal is carried out in compliance with all safety measures for the operator and the environment. This is also confirmed by the results of the operator's urine tests taken by us during the inspection. At a rate of up to $10 \mu \mathrm{g} / \mathrm{l}$, the mercury content in the urine was from 1.21 to $3.76 \mu \mathrm{g} / 1$ (tested 5 operators for 5 years). The mercury content in the air of the working area at the operator's workplace in the breathing zone was within the TVL w.z. (0.004 \pm $\left.0.002 \mathrm{mg} / \mathrm{m}^{3}\right)$ (10 measurements over 5 years). Operators use the recommended PPE. The room with the installation for utilization of mercury lamps is equipped with a powerful system of supply and exhaust ventilation. On the territory of the enterprise near the exhaust ventilation pipe, the level of $\mathrm{Hg}$ was slightly higher $\left(0.006 \pm 0.002 \mathrm{mg} / \mathrm{m}^{3}\right)$, but also did not exceed the TVL w.z. At the border of the sanitary protection zone, the level of $\mathrm{Hg}$ has always been much lower than average daily TLV $\left(0.0003 \mathrm{mg} / \mathrm{m}^{3}\right)$. Mercury concentrations ranged from $0.00004 \mathrm{mg} / \mathrm{m}^{3}$ to $0.0001 \mathrm{mg} / \mathrm{m}^{3}$ (depending on wind direction and speed and air temperature).

Thus, an enterprise that is able to recycle mercury lamps without harming the environment and human health is working fruitfully in Odessa. The user's task is to bring the used lamp to the hazardous waste collection point, and the state's task is to ensure the availability of such points.

The draft Law of Ukraine "On Ratification of the Minamata Convention on Mercury" (March 29, 2018) was developed by the Ministry of Ecology and Natural Resources of Ukraine due to the urgent need to take measures and recognize serious consequences for human health and the environment resulting from pollution $\mathrm{Hg}$, as well as the need to ensure proper regulation of production activities using $\mathrm{Hg}$. The need for legal regulation of this issue, primarily due to the lack of regulations in the legal system of Ukraine, which would comprehensively regulate the treatment of $\mathrm{Hg}$, economic activities in which this toxicant is used, contained provisions on the restriction or withdrawal from circulation of products containing $\mathrm{Hg}$. The Resolution of the Verkhovna Rada of Ukraine of January 14, 2020 № 457-IX approved the recommendations of the parliamentary hearings on the topic: "Priorities of the environmental policy of the Verkhovna Rada of Ukraine for the next five years". It states: "Many environmental issues can be addressed through the introduction of strong and effective environmental supervision based on state environmental monitoring. At the same time, the solution to pollution problems must take place in a constant constructive dialogue between government and business". This document recommends accelerating accession to the Minamata Convention on Mercury.

We have focused in detail on one, unfortunately, many, specific case of violation of the rules of toxic (mercury-containing) waste to illustrate the complexity of the problem, the differences between the declarations on the implementation of preventive environmental measures and the realities on the ground. In Ukraine, at the national level, as well as in each region, excellent in terms of content environmental policy documents are regularly developed and adopted. Among them are "Solid Waste Management Programs" for the next 5 years, as is the case, for example, in the Odessa region. Our institute has repeatedly participated in the development of such programs in the 2000s [27-29]. A modern methodological framework has been created, pilot projects have been implemented, and a number of proposals have been substantiated to prevent the dangerous effects of heavy metals, primarily on the health of children in the region. But the enthusiasm of those responsible quickly passed, the work of scientists was postponed, the plans were not implemented. Therefore, the new "Program" for 2018-2022 is practically not implemented. By certain indications, this situation is typical for other regions as well. Therefore, we illustrate this crucial issue with a concrete example to involve a wide range of scientists and practitioners who are not indifferent to the problems of environmental protection in our country, to include all regions in this work, with further unification at the national level. Think globally, act locally - this is the motto of our daily work, including in solving environmental problems in the region.

We are convinced that the way to the safe 
use of mercury compounds lies not through the ban on the use of mercury where it is economically and technologically necessary, but through the state program of mercury-containing waste management, which should begin with environmental education and upbringing of children and adults. Include state control over the collection and disposal of mercury-containing waste, at the state level to ensure the operation of hazardous waste collection points for the population. It is necessary to develop and adopt acts that establish penalties for improper handling of hazardous waste. The state must find the means to carry out proper environmental monitoring of $\mathrm{Hg}$ content in the environment. After all, we must always remember, "We did not inherit the earth from our ancestors. We borrow it from our descendants."

\section{Conclusions}

1. Without proper disposal, mercury lamps are hazardous to the environment and human health.

2. Mercury lamps should be collected and disposed of as hazardous waste not only in industrial facilities but also in the general public. The formation of spontaneous unauthorized landfills of mercury lamps is unacceptable.

3 . It is necessary to solve the problem of environmental monitoring at the state level with the obligatory involvement of specialists in the field of hygiene, toxicology and analytical chemistry of heavy metals in cases of violations to assess the level of danger and make balanced decisions on approaches to mercury sources.

The autors declare that there are no conflicts of interest

1. Trakhtenberg IM, Korshun MN. Mercury and its compounds in the environment: (Hygienic and environmental aspects). Higher school, 1990.

2. Bolshoy DV. Hygienic significance of the features of toxicokinetics, toxicodynamics and biotransformation of small doses of mercury [Text]: dis ... Cand. biol. Sciences 14.02.01 Bolshoy Dmitry Valerievich; Ukrainian Research Institute of Transport Medicine. O: 2007. 167 p.

3. Panait EV. Geochemistry of mercury of natural and man-made origin in environmental objects: author's ref. dis. Cand. geol. Sciences: 04.00.02, Geochemistry. K: 2016. 20 p.

4. Bolshoy DV, Pykhtieieva EG. Comparative evaluation of metabolic disorders under the action of low doses of cadmium and mercury. Actual problems of transport medicine. 2006; 1 (3): 12-8.

5. Smolyar VI. Mercury in food and rations and its toxicity: a scientific publication. Problems of nutrition: scientific and practical journal. 2008; 3: 23-31.

6. Trdin A, Tratnik JS, Mazej D, Fajon V, Krsnik M, Osredkar $J$ et al. Mercury speciation in prenatal exposure in Slovenian and Croatian population-PHIME study. Environmental research. 2019; 177: 108-627.

7. Planchart A, Green A, Hoyo C, Mattingly CJ. Heavy metal exposure and metabolic syndrome: evidence from human and model system studies. Current environmental health reports. 2018; 5(1): 110-24.

8. Yorifuji T. Lessons from an early-stage epidemiological study on Minamata disease. Journal of epidemiology. 2019; JE20190089.

9. Yorifuji T, Takaoka S, Grandjean P. Accelerated functional losses in ageing congenital Minamata disease patients. Neurotoxicology and teratology. 2018; 69: 49-53.

10. Olson C, Fakhraei H, Driscoll CT. Mercury Emissions, Atmospheric Concentrations, and Wet Deposition across the Conterminous United States: Changes over 20 Years of Monitoring. Environmental Science \& Technology Letters. 2020; 7(6): 376.

11. Martin LG, Labuschagne C, Brunke EG, Weigelt A, Ebinghaus R, Slemr F. Trend of atmospheric mercury con- centrations at Cape Point for 1995-2004 and since 2007. Atmospheric Chemistry \& Physics 2017; 17(3): 2393-99.

12. Streets DG, Horowitz HM, Jacob DJ, Lu Z, Levin L, Ter Schure AF et al. Total mercury released to the environment by human activities. Environmental Science $\&$ Technology. 2017; 51(11): 5969-77.

13. Blum JD, Sherman LS, Johnson MW. Mercury isotopes in earth and environmental sciences. Annual Review of Earth and Planetary Sciences. 2014; 42: 249-69.

14. Obrist D, Kirk JL, Zhang L, Sunderland EM, Jiskra M, Selin NE. A review of global environmental mercury processes in response to human and natural perturbations: Changes of emissions, climate, and land use. Ambio. 2018; 47(2): 116-40.

15. Pacyna EG, Pacyna JM, Steenhuisen F, Wilson S. Global anthropogenic mercury emission inventory for 2000. Atmospheric environment. 2006; 40(22): 4048-63.

16. Sprovieri F, Pirrone N, Bencardino M, D'Amore F, Carbone F, Cinnirella $\mathrm{S}$ et al. Atmospheric mercury concentrations observed at ground-based monitoring sites globally distributed in the framework of the GMOS network. Atmospheric chemistry and physics. 2016; 16(18): 119-15.

17. Kwon SY, Blum JD, Yin R, Tsui MTK, Yang YH, Choi JW. Mercury stable isotopes for monitoring the effectiveness of the Minamata Convention on Mercury. Earth-Science Reviews. 2020; 203: 103-11.

18. Determination of mercury content in production facilities, environment and biological materials. MV 10.1115-2005. K: 2005.48 p.

19. Kuzmin RS. Component composition of waste. Part 1: monograph. Kazan Printing House. 2007.

20. Bagotsky VS, Skundin AM, Volfkovich YM. Electrochemical power sources: batteries, fuel cells, and supercapacitors. John Wiley \& Sons. 2015.

21. Liang R, Wu ZY, Yang WM, Tang ZQ, Xiong GG, Cao YC et al. A simple one-step molten salt method for synthesis of micron-sized single primary particle LiNi 0.8 Co $0.1 \mathrm{Mn}$ $0.1 \mathrm{O} 2$ cathode material for lithium-ion batteries. Ionics. 2020; 26(4): 1635-43. 


\section{ECOTOCXICOLOGY}

22. Shafran LM, Loeva ID, Zasypka LI, Shafran KL. Toxicology and ecology of mercury (to the problem of environmental improvement in the region): Sat. scientific articles. Odessa: OSTNEI, 1999. 354-9.

23. https: //censor.net.ua/ua/p4519427

24. https: //varianty.lviv.ua/67502-na-pustomytishchyni-vyiavyly-nezakonne-zvalyshche-liuministsentnykh-lamp

25. https: //varianty.lviv.ua/70095-poblyzu-lvova-vyiavylynezakonne-zvalyshche-liuministsentnykh-lamp

26. https: //dilo.net.ua/kryminal-i-koruptsiya/bilya-gorodkaznajshly-skopyshhe-vidpratsovanyh-rtutnyh-lamp/

27. Shafran LM, Skrinnik LA. Waste management is a priority in the problem of sustainable development of the region (commentary on the regional program for the management of toxic waste in the Odessa region for 2002-2005). Black Sea Ecological Bulletin. 2002; 1(1): 42-9.

28. Shafran LM, Bolshoy DV, Pykhtieieva EG, Timofieieva SV. The role of metallothioneins in the biomonitoring of environmental pollution by heavy metals Sat.: "Hygiene of populated areas". K: Issue. 2000; 37:190-3.

29. Shafran LM, Timoshina DP, Pykhtieieva EG, Timofieieva SV. A study of the risk of urban environmental environmental factors for public health. Ecological problems of cities, recreational areas and conservation areas. Sat. scientific articles. Odessa: OSTNEI.; 2000:337-40.

\section{ТОКСИКО-ЕКОЛОГІЧНИЙ АНАЛІЗ ПОВОДЖЕННЯ З РТУТЬВМІСНИМИ ВІДХОДАМИ В УКРАЇНІ О.Г. Пихтєєва, Д.В. Большой, Л.М. Шафран \\ ДП Український НДІ медицини транспорту, м. Одеса, Україна}

PEЗЮМЕ. Актуальність. Багатоаспектна міжгалузева проблема безпеки людства при контакті з ртуттю набула глобального значення у ХХ столітті, вона є актуальною і нині. Значну увагу привертають еколого-гігієнічні аспекти ртутної небезпеки на місиях, пов'язані з виробництвом продукції та утилізацією відходів з вмістом Нg.

Мета. Проаналізувати дані власних досліджень вмісту ртуті в об'єктах навколишнього середовища у зв'язку з поводженням з ртутьвмісними відходами та обгрунтувати комплекс профілактичних еколого-гігієнічних, технологічних і організаційних заходів для підвищення безпеки, охорони здоров'я населення та покращення стану довкілля в регіоні та країні в цілому.

Матеріали та методи. Відбір проб, пробопідготовку і визначення вмісту ртуті в об'єктах довкілля і біопробах проводили згідно з МВ «Методичні вказівки по визначенню ртуті в біологічному матеріалі, атмосферному повітрі, питній водi, продуктах харчування і об'єктах навколишнього середовища». Концентрацію ртуті вимірювали методом ААС «холодної пари» на модернізованому приладі «Юлія-2М». Досліджений вміст ртуті в грунті та повітрі на стихійному звалищі ртутних ламп в Одеській області, на межі санітарно-захисної зони та в повітрі робочої зони підприємства з утилізації ртутних ламп. Для пробопідготовки використовували х.ч. азотну кислоту (56 \%), для відновлення ртуті під час аналізу х.ч. хлорид олова (II). Результати. Показано, що без утилізації належним чином ртутні лампи небезпечні для навколишнього середовища $і$ здоров'я людей. Ртутні лампи повинні збиратися і утилізуватися як небезпечні відходи не тільки на промислових об'єктах, а й у населення. Утворення стихійних несанкціонованих звалищ ртутних ламп неприпустиме. Необхідно на держсвному рівні вирішити проблему моніторингу довкілля з обов'язковим залученням фахівців у галузі гігієни, токсикології та аналітичної хімії важких металів у випадках виявлення порушень для оцінки рівня небезпеки і прийняття зважених рішень щодо підходів до ліквідації джерел надходження ртуті.

Ключові слова: ртуть, ртутні лампи, екологія.

\section{ТОКСИКО-ЭКОЛОГИЧЕСКИЙ АНАЛИЗ ОБРАЩЕНИЯ С РТУТЬСОДЕРЖАЩИМИ ОТХОДАМИ В УКРАИНЕ}

Е.Г. Пыхтеева, Д.В. Большой, Л.М. Шафран

ГП Украинский НИИ медицины транспорта, г. Одесса, Украина

РЕЗЮМЕ. Актуальность. Многоаспектная межотраслевая проблема безопасности человечества при контакте с ртутью приобрела глобальное значение в ХХ веке и остается актуальной в настоящее время. Большое внимание привлекают эколого-гигиенические аспекты ртутной опасности на местах, связанные с производством ртутьсодержсащей продукции и утилизацией содержащих $\mathrm{Hg}$ отходов.

Цель. Проанализировать данные собственных исследований содержания ртути в объектах окружающей среды в связи с обращением с ртутьсодержащими отходами и обосновать комплекс профилактических эколого-гигиенических и организационных мер по повышению безопасности, охраны здоровья населения и улучшению состояния окружающей среды в регионе и стране в целом.

Материалы и методы. Отбор проб, пробоподготовку и определение содержсания ртути в объектах окружающей среды и биопробах проводили в соответствии с МУ «Методические указания по определению ртути в биологическом материале, атмосферном воздухе, воде, продуктах питания и объектах окружающей среды». Концентрацию ртути измеряли методом $A A C$ «хлодного пара» на модернизированном приборе «Юлия-2М». Исследовали содержание ртути в почве и воздухе на стихийной свалке ртутных ламп в Одесской области, на границе санитарно-защитной зоны и в воздухе рабочей зоны предприятия по утилизации ртутных ламп. Для пробоподготовки использовали х.ч. азотную кислоту (56\%), для восстановления ртути при анализе х.ч. хлорид олова (II).

Результаты. Показано, что без утилизации должным образом ртутные лампы опасны для окружающей среды и здоровья людей. Ртутные лампы должны собираться и утилизироваться как опасные отходы не только на промышленных объектах, но и у населения. Образование стихийных несанкционированных свалок ртутных ламп недопустимо. Необходимо на государственном уровне решить проблему мониторинга окружающей среды с обязательным привлечением специалистов в области гигиены, токсикологии и аналитической химии тяжелых металлов в случаях выявления нарушений для оценки уровня опасности и принятия взвешенных решений относительно подходов к ликвидации источников поступления ртути. Ключевые слова: ртуть, ртутные лампы, экология.

Received 22/06/2020 